\title{
MUNICIPAL BUDGET OUTLOOKS: ARE THEY REALLY UTILISED?
}

\author{
[Rozpočtové výhledy obcí: Opravdu se využívají?] \\ Lucie Sedmihradská ${ }^{1}$ \\ ${ }^{1}$ University of Economics, Faculty of Finance and Accounting, nám. W. Churchilla 4, 13067 Praha 3 \\ Email:sedmih@vse.cz
}

\begin{abstract}
The objective of the paper is to evaluate the role which the multi-year budget outlook has in the budgetary process and to explore its usage in the Czech municipalities. The analysis is based on the published multi-year budget outlooks in 131 Czech towns with more than 10 thousand inhabitants and two case studies. Compilation of the multi-year budget outlook in the Czech Republic is compulsory and its legal regulation allows a broad range of existing practice. Only about a half of the towns publishes a valid multi-year budget outlook on the Internet. The time span of the documents is evenly distributed between two to five years and the detail differs considerably. While four towns prepare the whole budget in a multiannual perspective, about a third of the multi-year budget outlooks contains only the major types of revenue and expenditure. More than one quarter of the published multi-year budget outlooks is prepared by external consultants. The lack of regular update and high uncertainty about future revenue significantly limit the information value of the document.
\end{abstract}

Keywords: budgetary process, fiscal transparency, local government, multi-year budget outlook.

JEL classification: $\mathrm{H} 72$

Doručeno redakci: 14.10.2015; Recenzováno: 27.10.2015; 5.11.2015; Schváleno k publikování: 23.3.2016

\section{Introduction}

Annual budget covers a period of one year which implies that long term consequences of today's decisions are not shown. Prudent financial planning however requires a multiyear perspective in order to react in advance to changes in the environment. This disproportion can be solved by a multi-year budget outlook which lengthens the time perspective of the elected officials beyond their term in office (Schroeder, 1982). At the same time the preparation of the annual budget should be based on the multi-year budget outlook (Kotrba, 2003). These are the major reasons why Czech local governments are required to compile multi-year budget outlook which covers a period of 2 to 5 years. This requirement has been in force since 2001 but only since 2009 there has been a penalty in case of violation of this requirement.

The law gives only a general framework and we know very little about the current praxis. Hrabalová et al. (2004) surveyed all Czech towns regarding their use of the multi-year budget outlook and found out that the real usage is quite limited and that the towns lack decent methodical guidance. Klíma (2011) questions the utilization of the multi-year budget outlook based on a case study.

The objective of the paper is to evaluate the role which the multi-year budget outlook has in the budgetary process and to explore its usage in the Czech municipalities. The analysis is based on published multi-year budget outlooks in 131 Czech towns with more than 10 thousands inhabitants and two case studies.

First the multi-year budget outlook is characterized and its legal regulation in the Czech Republic described. Then there are presented two case studies which show the links between multi-year budget outlooks and approved budgets. Next the major results of the undertaken survey are presented and discussed. Conclusions are drawn in the final section. 


\section{Multi-year budget outlook as a part of the municipal budgetary process}

The multi-year budget outlook plays a double role in the budgetary process: firstly, it is a starting point for preparation of the draft budget and secondly, it shows long-term impacts of current or past decisions. It places the annual budget in a multi-year perspective. The annual budget cycle is enhanced by the multi-year budget outlook, i.e. the multiyear expenditure and revenue projections (Boex at al., 2000).

Budget preparation is based on the multi-year budget outlook (Schneiderová, 2006) and all new facts, e.g. legal changes, macroeconomic situation, decision of municipal bodies and new contracts, modify the original estimates or projections.

The major purpose of the multi-year budget outlook is to bring new information into the budgetary process and to overcome the myopic attitudes often exhibited in the annual budget process (Bahl and Schroeder, 1984). The multi-year budget outlook can serve as an "early warning signal" if there is a gap between projected revenue and expenditure, which allows to take the necessary steps to overcome the problem (Bahl and Schroeder, 1984). The major drawbacks of the multi-year budget outlook is great uncertainty about the future and need of frequent and substantial revisions (Joumard et al., 2004). At the same time the Czech municipalities deal with sizable effects fully out of hands of municipal officials: municipalities rely on high shares of intergovernmental transfers which are only approved in the course of the budget year and cannot thus be projected for a longer period and hence included in the multi-year budget outlook (e.g. Tesař (2015) does not include conditional investment grants and the related capital expenditure in the multi-year budget outlook of Litvínov).

However despite these limitations the multi-year budget outlook can provide information which is otherwise during the decision making often missing: Decision concerning a new capital project should take into account not only the current costs but also the future operating and maintenance spending and debt service costs in case of debt financing (Schroeder, 1982). Other uses include consideration of fiscal impact of zoning (i.e. spatial planning) and of course changes in demographic and economic situation.

The multi-year budge outlook is useful only if it is monitored and updated regularly. Obrovský (2001) suggests to update it twice a year: together with the evaluation of the budget execution and in the middle of the year. Then the multi-year budget outlook for one more year is prepared.

The requirements for local governments to compile the multi-year budget outlook is present in the Budgetary rules for local governments (Act No. 250/2000 Coll.) since 2001. The multiyear budget outlook is compiled for a period of two to five years. The major amendment came in 2009 when a penalty for noncomplying local governments was established. Another law amendment in 2006 specified that long term consequences have to be shown for the whole lifetime of the liability instead of only the limited time of the multi-year budget outlook.

Some of the municipalities used the multi-year budget outlook even before its legislation but its use became wider only after the new Budgetary rules were passed in 2000 (Obrovský, 2001). Due to the penalties for noncompliance we can assume, that the usage is today $100 \%$. The law does not require that the multi-year budget outlook is debated or approved by municipal council and there is no legal publicity requirement. The resulting practice is therefore quite rich. 
To sum up, the multi-year budget outlook can really enrich the annual budgetary process if it is updated regularly, if it is used as a basis for annual budget compilation, if it is as an important source of information disclosed to the public and if it is sufficiently detailed.

\section{Data and methods}

The research is based on elaboration of two case studies and a survey among all Czech towns with more the 10 thousand inhabitants.

The case studies deal with regional capital České Budějovice and district of the capital city Praha 10. Both of these local governments publish all of the current and past multi-year budget outlooks on their web pages and update the multi-year budget outlook annually. The only significant difference between the two local governments is the time of multi-year budget outlook compilation. While in case of Praha 10 the multi-year budget outlook is compiled during the preparation of the budget of the previous year, in case of České Budějovice it is compiled during summer, just when the preparation of the budget for the next year starts. Therefore, the two local governments are not compared but evaluated independently.

There were used two indicators. The respective indexes are used for the year covered and the year of approval $M Y B O_{\text {year of approval }}^{\text {year core }}$ MYBO stays for multi-year budget outlook. $0 \%$ means no adjustment and high positive values mean inclusion of new expenditure, high negative values mean cancelation of some previously included expenditure.

MYBO adjustment shows if the multi-year budget outlook is adjusted regularly.

$M Y B O$ adjustment $=\frac{M Y B O_{t-1}^{t}}{M Y B O_{t-2}^{t}}-1$

Budget adjustment shows if the approved budget is in line with the most recent multi-year budget outlook. $0 \%$ means that the approved budget was equal to the latest available multiyear budget outlook.

budget adjustment $=\frac{\text { budget }^{t}}{M Y B O_{t-1}^{t}}-1$

The survey dealt with 131 Czech towns and cities with more than 10 thousand inhabitants and the multi-year budget outlooks available on the Internet and took place between January and April 2015. The multi-year budget outlooks were searched either in 2015 draft budgets, 2015 approved budgets or separately published on the towns web pages. Only the multi-year budget outlooks that include at least the year 2016 were considered although the legal requirement is that the valid multi-year budget outlook should at the moment of the survey cover at least years 2016 and 2017 (Schneiderová, 2015). So, the multi-year budget outlooks covering any earlier periods were not considered.

For each of the collected multi-year budget outlook the following characteristics were evaluated:

- Published as a part of the budget or alone,

- Includes a commentary,

- Number of years covered,

- Level of detail and

- Prepared by external consultant. 
The obtained data were analyzed using the pivot tables and the difference of means test ( $\mathrm{t}-$ test).

\section{Evaluation of the multi-year budget outlook application: Two case studies}

The evaluation of the quality of the multi-year budget outlooks is very difficult, because its primary goal is not accuracy but provision of information, which leads to undertaking of appropriate policies (Schroeder, 1982). The projections are not forecasts what will happen in the future, but they are instruments to change the future and an important part of the process is yearly updating of the projections (Ulla, 2006).

On the other hand comparison of the multi-year budget outlooks and approved budgets for a longer period may give some clue, if the multi-year budget outlook is adjusted regularly and if it guides the preparation of the budget. If the multi-year budget outlook is used continually, then all the adjustments defined in equations (1) and (2) should be moderate.

The analysis of the multi-year budget outlooks in the district Praha 10 (Table 1) in 2012 and 2013 in case of current expenditure shows such continuous adjustment: In 2011 a moderate adjustment (4\%) of the multi-year budget outlook for 2012 took place and the budget was again moderately adjusted comparing to the multi-year budget outlook (-6\%). In contrary, in the years 2013 and 2014 the multi-year budget outlooks for the next years were not adjusted at all $(0 \%)$ and subsequently the approved budget exceeded significantly the earlier projections (42 and 55\%). It is necessary to note that this was not caused by external factors. About a quarter of the increase was caused by opening of a newly built elderly home, i.e. exactly the type of expenditure, which should be included in the multi-year budget outlook.

The analysis of the capital expenditure shows either very poor investment planning or none or late adjustment of the multi-year budget outlook. The share of capital expenditure financed through capital grants in the period 2010 to 2014 was only $10 \%$ hence the unpredictable impact of capital grants was quite limited. Between 2010 and 2012 the multi-year budget outlook was adjusted, but not enough and the approved budget contained many investments not covered by the multi-year budget outlook. In 2013 the multi-year budget outlook for 2014 was adjusted downward, but the approved budget was as high as the earlier projection. In 2014 the multi-year budget outlook was not adjusted at all.

Table 1: Multi-year budget outlook (MYBO) and budget adjustment in a Prague district

\begin{tabular}{|c|c|c|c|c|}
\hline \multirow[t]{2}{*}{$\mathrm{t}$} & \multicolumn{2}{|c|}{ Current expenditure } & \multicolumn{2}{|c|}{ Capital expenditure } \\
\hline & $\begin{array}{c}\text { MYBO } \\
\text { adjustment }\end{array}$ & Budget adjustment & $\begin{array}{c}\text { MYBO } \\
\text { adjustment }\end{array}$ & $\begin{array}{c}\text { Budget } \\
\text { adjustment }\end{array}$ \\
\hline 2011 & $12 \%$ & $18 \%$ & $475 \%$ & $63 \%$ \\
\hline 2012 & $4 \%$ & $-6 \%$ & $74 \%$ & $89 \%$ \\
\hline 2013 & $-2 \%$ & $4 \%$ & $90 \%$ & $37 \%$ \\
\hline 2014 & $0 \%$ & $42 \%$ & $-33 \%$ & $123 \%$ \\
\hline 2015 & $0 \%$ & $55 \%$ & $0 \%$ & $27 \%$ \\
\hline
\end{tabular}

Source: author, based on Městská část Praha 10 (2015)

The case of the regional capital České Budějovice is slightly different (Table 2). Three out of the seven multi-year budget outlooks analyzed were prepared by an external consultant. While this does not play any role in case of current expenditure, it does in case of capital expenditure. The external consultant projected much lower capital expenditure which result in higher values in case of both applied indicators and he did not adjust the projection in the 
individual years (0\% in 2013 in case of MYBO adjustment). The extremely high values in some of the indicators in case of the capital expenditure are caused by different approaches adopted by the city and the external consultant when preparing the multi-year budget outlook.

The adjustments in case of current expenditure are very small with only one exception impact of the change in the social allowances payments since 2012 which of course could not be predicted in the multi-year budget outlook compiled in 2011.

Table 2: Multi-year budget outlook (MYBO) and budget adjustment in a regional capital

\begin{tabular}{|r|r|r|r|r|}
\hline $\mathrm{t}$ & \multicolumn{2}{|c|}{ Current expenditure } & \multicolumn{2}{c|}{ Capital expenditure } \\
\hline & $\begin{array}{c}\text { MYBO } \\
\text { adjustment }\end{array}$ & Budget adjustment & $\begin{array}{c}\text { MYBO } \\
\text { adjustment }\end{array}$ & $\begin{array}{c}\text { Budget } \\
\text { adjustment }\end{array}$ \\
\hline 2009 & $10 \%$ & $5 \%$ & $46 \%$ & $9 \%$ \\
\hline 2010 & $3 \%$ & $-8 \% *$ & $-26 \%$ & $114 \% *$ \\
\hline 2011 & $-1 \% *$ & $-1 \%$ & $107 \% *$ & $18 \%$ \\
\hline 2012 & $-5 \%$ & $-16 \% *$ & $-65 \%$ & $172 \% *$ \\
\hline 2013 & $-19 \% *$ & $9 \%^{*}$ & $0 \% *$ & $185 \% *$ \\
\hline 2014 & $7 \% *$ & $0 \%$ & $190 \% *$ & $-2 \%$ \\
\hline 2015 & $3 \%$ & $3 \%$ & $-13 \%$ & $-9 \%$ \\
\hline
\end{tabular}

Source: author, based on Statutátní město České Budějovice (2015)

Note: * prepared by external consultant

These cases needn't to be representative, however they show that the multi-year budget outlook does not especially in case of capital expenditure serve as a reliable information source regarding future developments. At the same time the analysis shows that regular evaluation and adjustment of the multi-year budget outlook is not pervasive. Klíma (2011) came based on a case study to similar conclusions: the differences between the multi-year budget outlook and the approved budget are so big that it is obvious that during the process of budget approval nobody even looked at the multi-year budget outlook.

\section{The multi-year budget outlook in Czech towns}

Out of the 131 Czech towns with more than 10 thousand inhabitants there were collected 74 multi-year budget outlooks. This means that only $56.5 \%$ of towns publish these documents on-line. Out of them 33 were part of the 2015 budget and 41 were published independently. However 7 out of these 41 multi-year budget outlooks did not cover the year 2017, i.e. according to the legislation were not valid. If these multi-year budget outlooks are not calculated, then the on-line availability of the valid multi-year budget outlooks is only $51.1 \%$. The problem of the missing updated or valid multi-year budget outlooks is reported by Klíma (2011) as well.

This is quite surprising and raises a question if there are cases and how many when the multiyear budget outlook is only an internal document which is available neither for the public nor the council members. In many cases it is possible to find a council resolution approving the multi-year budget outlook but the multi-year budget outlook itself is not available. To verify the praxis of the multi-year budget outlook as an internal document would however be possible only through direct questioning.

Public disclosure of the multi-year budget outlook is a demonstration of fiscal transparency, i.e., full disclosure of all relevant fiscal information in a timely and systematic manner (OECD, 2002). The reasons for nondisclosure may be fear from disputes of political 
opponents regarding the validity of the forecasts (Schroeder, 1982, 125) or unsustainability of the fiscal policy of the ruling government (e.g. debate on multi-year budget outlook in district council at Praha 3 on 17 December 2013).

Regarding evaluation of fiscal transparency it is important how the multi-year budget outlook is presented, i.e. if it contains only the projections (tables) or if a narrative explaining both the assumptions and the consequences is presented. A narrative was part of 42 , i.e. $56.8 \%$ of the available multi-year budget outlooks. The narrative is prepared more often in towns where also the budget is accompanied by a narrative. In towns where the budget contains comparison with the previous year or years the valid multi-year budget outlook is available more often than in towns which do not.

The multi-year budget outlook should be compiled for a period of 2 to 5 years. In reality in one case the period is longer. There is no clear dominance of one time period. The five year multi-year budget outlook slightly prevails.

The preparation of the multi-year budget outlook can be, similarly to preparation of the draft budget centralized or decentralized. The centralized means that the multi-year budget outlook is prepared by the budget department without inputs from other departments. In case of a decentralized system the line departments prepare the multi-year budget outlook for their departments and the budget department compiles the overall multi-year budget outlook (Schroeder, 1982). The advantage of the centralized system is its simplicity, economy and administrative feasibility. It also facilitates timeliness and frequency and prevents possible strategic manipulation. Its major disadvantage is that it limits the involvement of department heads in prioritization and identification of cost cutting opportunities (Boex et al., 2000).

The multi-year budget outlook can be compiled by an external consultant as well. At least in 17 towns the multi-year budget outlook is compiled by external consultants. This is a significant increase since 2004, when only 5\% of towns with more than ten thousand inhabitants hired an external consultant (Hrabalová, 2004). The advantage of such an approach is consultants' greater technical expertise. On the other hand they may lack sufficient knowledge of the municipality. If the multi-year budget outlook is used only as once-a-year or even once-in a few years exercise its usefulness for the municipality is limited. In house preparation greatly facilitates its further use (Schroeder, 1982).

The detail of the multi-year budget outlook differs significantly among the analyzed towns (Table 3). In case of four towns the whole budget is compiled in a multiannual perspective, i.e. all the budget lines contain not only the proposed budget for 2015 but also the estimates for 2016 and 2017 and in one case even 2018. 15 towns present a very detailed multi-year budget outlook. In case of 26 towns (35\%) the multi-year budget outlook only contains the major budget classes and in case appropriate the existing liabilities. The remaining 29 towns are somewhere in between: their multi-year budget outlook shows more detail using either organizational or economic classification or presenting a detailed overview of planned investments. Multi-year budget outlooks prepared by external consultants always use the second level of detail of the economic classification. Multi-year budget outlooks prepared by the towns themselves use more often own level of detail. 
Table 3: Characteristics of the published multi-year budget outlooks

\begin{tabular}{|c|c|c|c|c|c|}
\hline & \multicolumn{3}{|c|}{ Level of detail } & \multirow[b]{2}{*}{ Total } \\
\hline & & Budget classes & More detailed & Very detailed & \\
\hline \multicolumn{2}{|l|}{ Total } & 26 & 29 & 19 & 74 \\
\hline \multirow{5}{*}{ Years covered } & 2 & 8 & 3 & 9 & 20 \\
\hline & 3 & 6 & 4 & 4 & 14 \\
\hline & 4 & 5 & 5 & 4 & 14 \\
\hline & 5 & 6 & 17 & 2 & 25 \\
\hline & 6 & 1 & & & 1 \\
\hline \multirow{2}{*}{ Part of the draft budget } & no & 9 & 19 & 13 & 41 \\
\hline & yes & 17 & 10 & 6 & 33 \\
\hline \multirow{2}{*}{ Narrative } & no & 13 & 7 & 12 & 32 \\
\hline & yes & 13 & 22 & 7 & 42 \\
\hline \multirow{2}{*}{ External consultant } & no & 26 & 12 & 19 & 57 \\
\hline & yes & & 17 & & 17 \\
\hline
\end{tabular}

Source: author, based on a survey of 74 multi-year budget outlooks

There is no systematic relationship between the level of detail and the size of the town, however the multi-year budget outlook in the detail of the budget is in place in smaller towns in the sample. Multi-year budget outlooks presented as part of the annual budget cover on average a significantly shorter period (3.18 years) than multi-year budget outlooks presented independently (4 years). The narrative examining the multi-year budget outlooks is more common in case of less detailed outlooks and outlooks which were not part of the draft budget.

The obtained results show that despite the compulsory character of the multi-year budget outlooks they rarely bring the real benefits intended by the legislator. For instance the multiyear budget outlook is not considered an important information source if only about a half of the towns publishes it on the Internet. The situation in the remaining smaller municipalities is not likely to be better. The lack of regular update and high uncertainty about future revenue, especially capital transfers, significantly limits the information value of the document.

\section{Conclusions}

While the literature offers a long list of benefits a careful compilation and regular adjustment of an multi-year budget outlook can bring, the results of the presented research question their real existence in case of the Czech towns. The multi-year budget outlook does not bring any new information in the budgetary process if it is not detailed, regularly updated and public.

A survey among all 131 towns with more than ten thousand inhabitants showed that these necessary conditions are met quite rarely. A valid multi-year budget outlook is published on the Internet only in about a half of the surveyed towns and in a third of the towns the multiyear budget outlook contains only major revenue and expenditure categories and overview of liabilities, hence is not detailed enough. Two case studies showed that even in cases the multiyear budget outlook is prepared annually this update is quite formal and gives only little guidance in the preparation of the annual budget.

The research results do not lead to a straightforward recommendation. An obligation to publish the multi-year budget outlook on Internet is easy to legislate as well as to comply with. But will it bring new reliable information in the budgetary process? Not really. A real 
change would require a detailed and clear methodology for compilation and update of the multi-year budget outlook and, most of all, a stable financing of municipalities, i.e. no or long in advance approved tax sharing formula.

\section{Acknowledgements}

The paper is an output of the research project "Public finance in developed countries" supported by the Internal grant agency of the University of Economics, Prague, No. F1/2/2013 and a project of the Faculty of Finance and Accounting, which is carried out within the institutional support of the University of Economics in Prague, number IP 100040. The author thanks all the participants of the conference Veřejná ekonomika a správa 2015 for helpful comments.

\section{References}

[1] BAHL, R. and L. SCHROEDER, 1984. The Role of Multi-Year Forecasting in the Annual Budgeting Process for Local Governments. Public Budgeting \& Finance, 4(1), 3 13. ISSN $1540-5850$

[2] BOEX, L. F., J. MARTINEZ-VAZQUEZ and R. M. McNAB, 2000. Multi-Year Budgeting: A Review of International Practices and Lessons for Developing and Transitional Economies. Public Budgeting \& Finance, 20(2), 91-112. ISSN 1540-5850

[3] Budgetary rules for local governments, Act No. 250/2000 Coll.

[4] HRABALOVÁ, S. et al., 2004. Využivání rozpočtových výhledi̊ při ř́zení měst v ČR: analýza současné situace [online]. [cit. 12 ${ }^{\text {th }}$ May 2015]. Acessible from: is.muni.cz/www/3827/vysledky_vyzkumu_3.html

[5] JOUMARD, I. et al., 2004. Enhancing the Effectiveness of Public Spending: Experience in OECD Countries. OECD Economics Department Working Papers, 380.

[6] KLÍMA, M., 2011. Rozpočtový výhled nelze odbýt. Moderní obec [online]. 17(11) [cit. $10^{\text {th }}$ October 2015]. Acessible from: moderniobec.cz/rozpoctovy-vyhled-nelze-odbyt/

[7] KOTRBA, R., 2003. Rozpočtový výhled, návrh rozpočtu, přezkum hospodaření (odpovědi na dotazy z oblasti hospodařeni města) [online]. [cit. 15 ${ }^{\text {th }}$ May 2015]. Acessible from: www.kr-jihomoravsky.cz/archiv/linux/metodicke_listy/oe/rozp0305.htm

[8] MĚSTSKÁ ČÁST PRAHA 10, 2015. Rozpočet [online]. [cit. 10 ${ }^{\text {th }}$ April 2015]. Acessible from: praha10.cz/mestska-cast/finance/rozpocet.aspx

[9] OBROVSKÝ, J., 2001. Rozpočtový výhled ano či ne? Moderní obec [online]. 7(2) [cit. $10^{\text {th }}$ October 2015]. Acessible from: moderniobec.cz/rozpoctovy-vyhled-ano-ci-ne/

[10] OECD, 2002. Best Practices for Budget Transparency [online]. [cit. 15 ${ }^{\text {th }}$ May 2015]. Acessible from: www.oecd.org/dataoecd/33/13/1905258.pdf

[11] SCHNEIDEROVÁ, I., 2006. Rozpočtová skladba v roce 2006 a rozpočtový proces. Rožd'alovice: REVOS-L. ISBN 80-903160-3-49.

[12] SCHNEIDEROVÁ, I., 2015. Materiál ke knize Rozpočtová skladba 2015 [online]. [cit. $25^{\text {th }}$ June 2015]. Acessible from: www.obecuctuje.cz/dokumenty.php

[13] SCHROEDER, L., 1982. Local government multi-year budgetary forecasting: Some administrative and political issues. Public Administration Review, 42(2), 121-127. ISSN $1540-6210$. 
[14] STATUTÁRNÍ MĚSTO ČESKÉ BUDĚJOVICE, 2015. Rozpočtové výhledy města České Budéjovice [online]. [cit. 12 ${ }^{\text {th }}$ October 2015]. Acessible from: www.cbudejovice.cz/cz/magistrat/odbory/fo/stranky/rozpoctovy-vyhled.aspx

[15] TESǍ̌, L., 2015. Rozpočtový výhled Litvínova s analýzou financí a ratingem [online]. [cit. 15 $5^{\text {th }}$ May 2015]. Acessible from: www.mulitvinov.cz/VismoOnline_Action Scripts/File.ashx?id_org=8604\&id_dokumenty=449374

[16] ULLA, P., 2006. Assessing fiscal risks through long-term budget projections. OECD Journal on Budgeting, 6(1), 127-187. ISSN 1681-2336. 